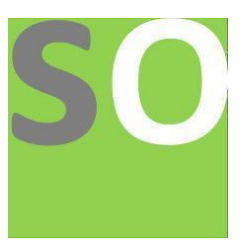

Article title: VERTICAL GREENING SYSTEM FOR ENVIRONMENT RESPONSIVE ARCHITECTURE: the Case of Multistory Buildings in Addis Ababa

Authors: Aksan Girma[1]

Affiliations: Architecture, Addis Ababa Science and Technology University[1]

Orcid ids: 0000-0001-8345-6668[1]

Contact e-mail: achsahngirma@gmail.com

License information: This work has been published open access under Creative Commons Attribution License http://creativecommons.org/licenses/by/4.0/, which permits unrestricted use, distribution, and reproduction in any medium, provided the original work is properly cited. Conditions, terms of use and publishing policy can be found at https://www.scienceopen.com/.

Preprint statement: This article is a preprint and has not been peer-reviewed, under consideration and submitted to ScienceOpen Preprints for open peer review.

DOI: 10.14293/S2199-1006.1.SOR-.PP4CI07.v1

Preprint first posted online: 25 August 2021

Keywords: vertical greening, vertical greening system, green wall, green façade, responsive architecture 


\section{VERTICAL GREENING SYSTEM FOR ENVIRONMENT RESPONSIVE ARCHITECTURE}

\section{The Case of Multistory Residential Buildings in Addis Ababa}

\section{Aksan Girma Gebre}

Department of Architecture, College of Architecture and Civil Engineering

Keywords: Vertical greening systems (VGS), Vertical Greening, Green Wall, Green Facade, System, Environment, Responsive architecture

\section{contents}

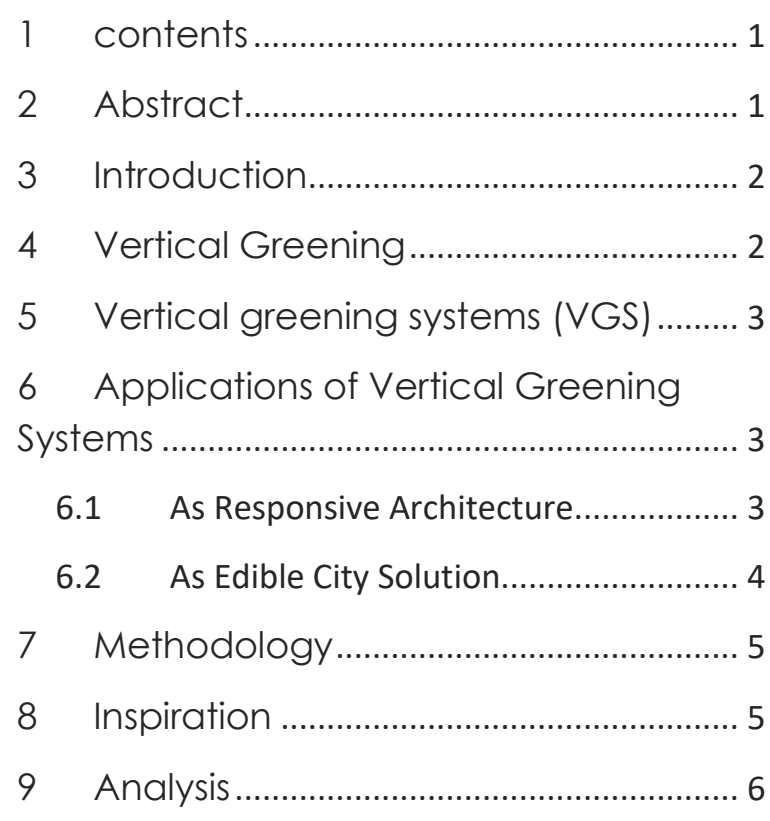

1. Buildings with vertical green .................. 6

2. Buildings without vertical green ............. 7

10 Finding and Comparative Analysis 8

11 Conclusion .......................................... 8

12 Recommendation ............................ 9

13 Reference........................................... 9

\begin{abstract}
Vertical greening systems can help mitigate the urban heat islands, increase the thermal efficiency of the buildings, save cooling energy and enhance air quality by using the vegetation's natural processes. However, since vertical greening schemes need materials and energy to be built, there are questions about whether they actually deserve to be adopted and how their environmental efficiency can be improved. The study aims to evaluate vertical greening systems' environmental efficiency and to study essential factors for efficient and sustainable building construction.
\end{abstract}




\section{Introduction}

Rapid urbanization is causing considerable ecological and environmental problems in our city, Addis Ababa. As the only large city in Ethiopia, vacant spaces are being taken by individuals and the government in order to meet the desperate need for shelter. Therefore, Vertical greening systems (VGS) allow vegetation to spread over a building facade or inside wall. VGS is considered a sustainable and green construction approach in the world. They will help reduce the urban heat island, enhance the thermal efficiency of buildings, save cooling resources and improve air quality by using natural processes of vegetation. (PerezUrrestarazu, et al., 2016), (Perini, et al., 201 1; Sheweká and Mohamed, 2012). (Ma, et al., 2013; Perini, et al., 2013)

This Journal aims to evaluate VGS' environmental efficiency and examine critical factors for efficient and sustainable construction design.

\section{Vertical Greening}

Population growth and urbanization have put pressure on basic necessities such as food, water, and housing (Cohen 2006). In the last five years, the worldwide urban population has increased by more than $50 \%$. All of these are possible outcomes of unrestrained population growth. In response to these issues, peri-urban gardening has gained popularity as a means of providing green spaces, improving air quality, and reducing urban heat in urban areas.

A new concept in green infrastructure is vertical greenery, where plants are integrated into vertical surfaces. Numerous modern techniques have been created in recent years to grow a variety of plants vertically. Climbing plants with self-clinging roots grew directly on the building surfaces, twining plants grew on trellises and pergolas, and plants grew within the cracks of piled boulders.

Vertical greening has numerous significant benefits, including: Beauty abounds and adds visual drama, covers up views of plain or ugly walls and provides building protection. Live plants decrease stress levels, create peaceful ambiance, Increases value and salability of residence building. Reduces $\mathrm{CO} 2$ levels and increases oxygen and improved air 
quality. Prevent from dust and harmful microorganisms, Plants are less accessible to diseases and pests.

\section{Vertical greening systems (VGS)}

Vertical greening systems (VGS) are structures that allow vegetation to spread over a building facade or interior wall. They can contribute to mitigating urban heat island, enhancing building's thermal performance, saving cooling energy and improving air quality. VGS are considered a sustainable/green building design approach (Sheweka and Mohamed, 2012) and are becoming increasingly popular in the urban landscapes. As the space available for greening is often very limited in urban cities, vertical greening can be an effective method applied to the exterior and interior surfaces of buildings to improve the city environment.

Vertical Greening Systems (VGS) is a system which allows vegetation to spread over a façade of a building. It will help to reduce the environment, increase thermal efficiency of the house, reduce cooling capacity and improve air quality. VGS is a safe and green approach to building architecture (Sheweka and Mohamed, 2012)

\section{Applications of Vertical Greening Systems}

\section{As Responsive Architecture}

1. Mitigating energy consumption

According to studies, Ivy vine sunscreen, growing on a wall can effectively shade a west-facing wall, reducing heat absorption and lowering indoor temperatures (Hoyano, 1988, 188). reduction of Urban Heat Island effect (UHI)

2. Elevate the thermal performance of buildings (lowering energy costs)

Plants, such as green roofs and walls, can reduce the air temperature around a structure in hotter weather, which not only reduces cooling costs but also reduces a building's UHI. (Alexandri 2006).

3. the improvement of water-sensitive urban They are sometimes referred to as bio-walls. As indoor air is taken through the living wall, carbon dioxide (CO2) and hazardous chemicals such as Volatile Organic Compounds are absorbed by the plants and planting media (Darlington, 1998). 


\section{4. improvement of Indoor Air Quality}

Plants and their planting media may be efficient sound barriers, as demonstrated on many motorways (Haron 2007). For the time being, the efficiency of green roofs for sound attenuation must be extrapolated from research on green roofs, and would be in densely populated cities, living wall systems can help reduce sound reflection from hard surfaces such as roads and buildings.

5. noise pollution reduction

Plants and their planting media may be good sound barriers, as observed on many roads. This helps for sound reflection from highways and buildings can be reduced by using living wall systems in cities that are becoming more congested (Haron 2007).

6. health and well-being improvement

In one study on workers in the USA and Norway who worked in offices with indoor plants or window views reported better job satisfaction in recent polls (Dravigne, 2008 and Bringslimark, 2007).

Living walls are an emerging technology that can also be used to promote outdoor living and walkability in cities. Their added greenery can lower ambient temperature and moderate the harsh nature of many urban structures.

\section{7. city-wide biodiversity and food}

As a consequence of green roof initiatives, there has been an increase in native flora and fauna species, and it is not unrealistic to assume comparable outcomes. Also, the potential for producing food on living walls has attracted attention throughout the world. In Ethiopia, many people who are currently living on vertical structures used to own their vegetable gardens while they were living on the ground. I will discuss it more briefly in the Edible City Solution section.

\section{As Edible City Solution}

Edible plants in vertical green systems boost the local environment and the urban ecosystem's harvestable products potential. The integration of facade technology into major cities of the world has been widely deployed and (Al-Kodmany, 2014). Al-Kodmany (2014) points out that their enhanced environmental performance and dramatic visual 
effect support a range of technical features that accommodate vertical urban farming, aesthetics, efficient thermal performance, daylight penetration, and interior environment control. These systems can also improve the holistic approach to buildings by combining food, housing, and integrated ecological solutions, which is an increasing demand in today's world.

\section{Methodology}

I have used these seven measurements on the application of vertical greenery system as an environmental responsive design. My research will examine different vertically greened as well as problematic buildings of Addis Ababa. I have used to the following criterion identify the problematic buildings to minimize my selection:

1. The buildings to be assessed are to be within the certain areas of Addis Ababa (i.e., around Bole, Piazza and National Theatre because those areas are a potential city centers of Addis Ababa and architecture experimental sites.

2. Buildings with high visual exposure, environmental value and vulnerability for main road

3. Buildings with bare wall or space which is functionable in the installation process (

4. Their function must be mainly residential, (Apartments, row houses, Condominiums).

5. The building must have a potential trait which can be solved by vertical greening system. I have chosen the two defected buildings by the above criterion. Further I have observed their interior and exterior through visual survey, mapping, interview and questionnaire.

After I have analyzed the buildings by categorizing in two groups: 1. With vertical green and 2. Without vertical green. After that I have established a comparative analysis, compared their outcome and drafted a recommendation.

\section{Inspiration}

During my survey, I have seen people trying to install greeneries in unhostile environments. In condominiums, apartments, hotels, government offices and residentials with little space for greening. 

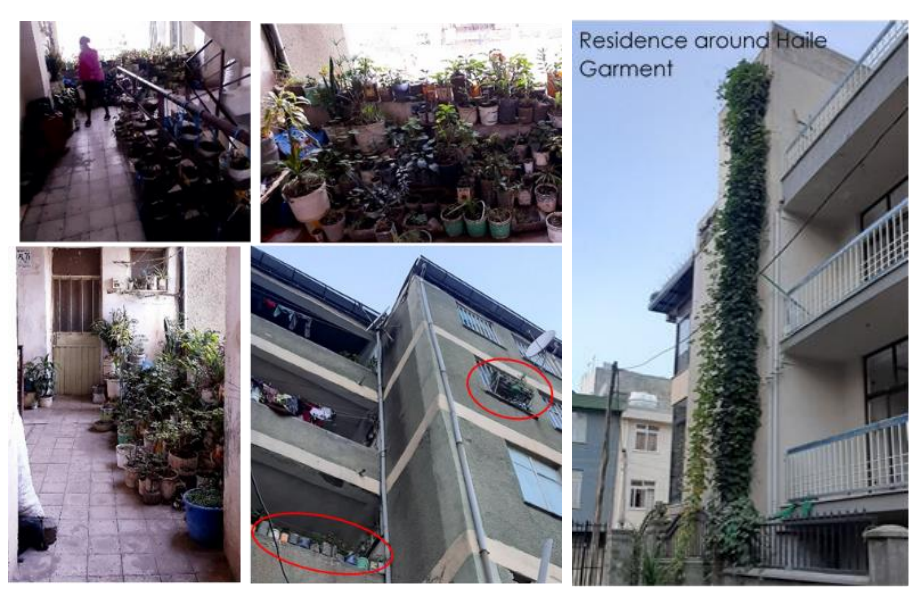

Figure 1:Ethiopia Addis Ababa, People planting in un hostile environment

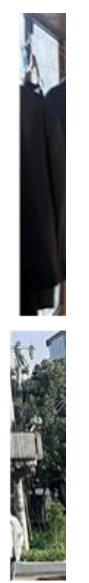

This implies that people are living in an environment which is away from nature by far, thus, they are desperately trying to be close to nature in any way as possible. During one of my interviews. A mother from one of Noah apartments implied that their apartment is the last place that she thought she would be raising her babies. She continued her concern about their future, her exact words were, I might not wonder if my children thought a banana or an apple is a fabricated product. this her words trigged me that we as a community need to elevate our concern about nature and the modern way of living, we cannot be bound on the ground, to plant trees and plants. We have to think to grow vertically. Unless otherwise we will face difficulties. Population is growing and it will continue to grow. But the land/ earth will not. So, what is our plan for our children?

The comparison below compares 4 different buildings, with 4 different functions, with different types of greening system and different types of materials. But the above all have vertical greenery. And in the first analysis, I have chosen vertical greenery attempts in Addis Ababa and their achievement. To conclude also whether vertical greenery is applicable in any type of building as long as the appropriate system is installed.

\section{Analysis}

\section{Buildings with vertical green}

I have reviewed four buildings, Varnero Apartment, Peace Building, ICS middle school building and Hope University Library. Based on function, two of them are apartment buildings which one of them is partially commercial, containing a bank and shops function and the other two are a class room and a library.

\begin{tabular}{|c|c|c|} 
Varnero apartment & $\begin{array}{c}\text { ICS, Middle school } \\
\text { building }\end{array}$ & $\begin{array}{c}\text { Peace } \\
\text { Building }\end{array}$ \\
\hline
\end{tabular}

Hope University Library 


\begin{tabular}{|c|c|c|c|c|c|}
\hline \multicolumn{2}{|c|}{ Stormwater management } & $\begin{array}{c}\text { ditch system, irrigation } \\
\text { watering }\end{array}$ & $\begin{array}{l}\text { Gutter, downpipes } \\
\text { ditch system, } \\
\text { underground pipes }\end{array}$ & $\begin{array}{l}\text { Downward gutter } \\
\text { to ditch }\end{array}$ & $\begin{array}{c}\text { Ditch } \\
\text { Flood occurred and } \\
\text { installed concrete } \\
\text { blocks }\end{array}$ \\
\hline \multicolumn{2}{|c|}{ Green Wall } & Climbers, Potted plants & $\begin{array}{c}\text { Modular Trellis Panel } \\
\text { System }\end{array}$ & $\begin{array}{c}\text { Balcony vertical } \\
\text { green }\end{array}$ & ----------- \\
\hline \multicolumn{2}{|c|}{ Green Roof } & On parking & $\begin{array}{c}\text { Expansive, dense } \\
\text { vegetation }\end{array}$ & ---------- & $\begin{array}{c}\text { Accessible dense green } \\
\text { roof }\end{array}$ \\
\hline \multicolumn{2}{|c|}{ Water Efficiency } & $\begin{array}{c}\text { alternative water } \\
\text { source (groundwater) }\end{array}$ & $\begin{array}{l}\text { Water-saving devices } \\
\text { and Alternative water } \\
\text { source (groundwater) }\end{array}$ & $\begin{array}{l}\text { Water-saving } \\
\text { accessories } \\
\text { (double flush), } \\
\text { Water-saving } \\
\text { green plants }\end{array}$ & $\begin{array}{l}\text { water saving device } \\
\text { (double flush) }\end{array}$ \\
\hline \multicolumn{2}{|c|}{ energy consumption } & Natural daylight & $\begin{array}{l}\text { Natural daylight } \\
\text { LED light bulbs } \\
\text { RE-solar energy }\end{array}$ & $\begin{array}{l}\text { Natural daylight } \\
\text { LED light bulbs } \\
\text { RE-solar energy }\end{array}$ & $\begin{array}{c}\text { Natural daylight, } \\
\text { fluorescent light bulbs, } \\
\text { LED }\end{array}$ \\
\hline \multirow[t]{3}{*}{$\begin{array}{l}\text { Materials and } \\
\text { Resources }\end{array}$} & Ceiling & stone steel roots & $\begin{array}{c}\text { cement tiles, } \\
\text { porcelain, Gypsum } \\
\text { board, green roof }\end{array}$ & concrete slab & $100 \%$ green roof \\
\hline & Wall & $\mathrm{HCB}$, & $\begin{array}{l}\text { HCB, fine quartz, } \\
\text { green wall }\end{array}$ & $\begin{array}{l}\text { Ceramic, green } \\
\text { façade }\end{array}$ & $\begin{array}{c}\text { Grass, HCB, Glass, } \\
\text { Bamboo }\end{array}$ \\
\hline & Floor & Ceramic, tree parquet & Linoleum, ceramic & ceramic tiles & Plastic tiles \\
\hline \multicolumn{2}{|c|}{ Waste management } & disposal site & recyclers & Collected daily & Collected daily \\
\hline \multirow{5}{*}{$\begin{array}{c}\text { Indoor } \\
\text { environmental } \\
\text { quality }\end{array}$} & Lighting & $\begin{array}{c}\text { Windows, Balcony } \\
\text { except toilets }\end{array}$ & $\begin{array}{l}\text { Windows, except } \\
\text { disabled bathrooms }\end{array}$ & Windows, & $\begin{array}{l}\text { large windows, two } \\
\text { open-downs, skylights }\end{array}$ \\
\hline & Ventilation & $\begin{array}{l}\text { natural ventilation, air } \\
\text { conditioning }\end{array}$ & $\begin{array}{l}\text { natural ventilation, air } \\
\text { conditioning }\end{array}$ & $\begin{array}{c}\text { natural } \\
\text { ventilation, air } \\
\text { conditioning }\end{array}$ & natural ventilation \\
\hline & $\begin{array}{l}\text { Thermal } \\
\text { comfort }\end{array}$ & $\begin{array}{c}\text { the back apartments } \\
\text { have higher } \\
\text { temperature }\end{array}$ & $\begin{array}{c}\text { Cooler (orientation) } \\
\text { Cladding materials } \\
\text { (stone) }\end{array}$ & $\begin{array}{c}\text { Balanced } \\
\text { (orientation) }\end{array}$ & $\begin{array}{c}\text { Cooler (green roofs, } \\
\text { orientation) }\end{array}$ \\
\hline & $\begin{array}{l}\text { Acoustic } \\
\text { and views }\end{array}$ & $\begin{array}{c}\text { noise reduction } \\
\text { materials }\end{array}$ & $\begin{array}{c}\text { noise pollution } \\
\text { Dumped by } \\
\text { Acoustic panel } \\
\text { fins }\end{array}$ & $\begin{array}{l}\text { noise pollution } \\
\text { Buffered by } \\
\text { the vertical } \\
\text { green }\end{array}$ & $\begin{array}{c}\text { noise pollution at } \\
\text { the back of the } \\
\text { building }\end{array}$ \\
\hline & $\begin{array}{c}\text { Dampness } \\
\text { and } \\
\text { microbial } \\
\text { growth }\end{array}$ & $\begin{array}{l}\text { Leakage under the } \\
\text { green roof, no } \\
\text { microbial growth }\end{array}$ & Not yet observed & None & $\begin{array}{l}\text { no dampness after } \\
\text { maintenance }\end{array}$ \\
\hline
\end{tabular}

\section{Buildings without vertical green}

The two buildings I, chose are Noah centrum real-estate apartment around Bole, Atlas and Bedilu building around Biherawi, Awash bank.

\begin{tabular}{|l|l|l|}
\hline & Noah Centrum Apartment & Bedilu Building \\
\hline Stormwater management & Gutter to Ditch & Gutter to Ditch \\
\hline Green Wall & No & No \\
\hline
\end{tabular}




\begin{tabular}{|c|c|c|c|}
\hline \multicolumn{2}{|l|}{ Green Roof } & No (Except One Private Green) & No \\
\hline \multicolumn{2}{|l|}{ Water Efficiency } & Tap water system, water tankers & Only tap water system \\
\hline \multicolumn{2}{|c|}{ Energy consumption } & Natural daylight (Extreme), no renewable & Natural daylight (Extreme) \\
\hline \multirow{3}{*}{$\begin{array}{l}\text { Materials and } \\
\text { Resources }\end{array}$} & Ceiling & Galvanized metal & Concrete slab \\
\hline & Wall & HCB, quartz paint & HCB, large glass windows \\
\hline & Floor & Ceramic & Ceramic tiles, marbles and concrete \\
\hline \multicolumn{2}{|c|}{ Waste management } & chute system & $\mathrm{NO}$ \\
\hline \multirow{5}{*}{$\begin{array}{l}\text { Indoor } \\
\text { environmental } \\
\text { quality }\end{array}$} & Lighting & Windows, extreme lighting & Windows, extreme lighting \\
\hline & Ventilation & Natural ventilation and mechanical ventilation & natural ventilation \\
\hline & $\begin{array}{l}\text { Thermal } \\
\text { comfort }\end{array}$ & Not vulnerable for heat, type of window & Vulnerable for heat \\
\hline & $\begin{array}{l}\text { Acoustic } \\
\text { and views }\end{array}$ & There is noise pollution & There is noise pollution \\
\hline & $\begin{array}{l}\text { Dampness, } \\
\text { microbial } \\
\text { growth }\end{array}$ & No leakage, no microbial growth & $\begin{array}{l}\text { leakage, there seems a microbial } \\
\text { growth, no proper waste disposal } \\
\text { place }\end{array}$ \\
\hline
\end{tabular}

Finding and Comparative Analysis

\begin{tabular}{|c|c|c|c|c|c|c|}
\hline & $\begin{array}{l}\text { Varnero } \\
\text { apartment }\end{array}$ & $\begin{array}{c}\text { ICS, Middle } \\
\text { school building }\end{array}$ & $\begin{array}{l}\text { Peace } \\
\text { Building }\end{array}$ & $\begin{array}{c}\text { Hope } \\
\text { University } \\
\text { Library } \\
\end{array}$ & $\begin{array}{l}\text { Noah Centrum } \\
\text { Apartment }\end{array}$ & Bedilu Building \\
\hline $\begin{array}{c}\text { Energy } \\
\text { consumption }\end{array}$ & $\begin{array}{c}\text { No mechanism } \\
\text { but good } \\
\text { lighting }\end{array}$ & Good efficient & $\begin{array}{l}\text { Good } \\
\text { efficient }\end{array}$ & Good efficient & No mechanism & $\begin{array}{c}\text { No } \\
\text { mechanism }\end{array}$ \\
\hline $\begin{array}{c}\text { Thermal } \\
\text { performance }\end{array}$ & Warmer & Cooler & Balanced & Cooler & Cooler & $\begin{array}{c}\text { Hot, the case } \\
\text { area side }\end{array}$ \\
\hline $\begin{array}{c}\text { Water-conserving } \\
\text { urban }\end{array}$ & $\begin{array}{l}\text { Irrigation } \\
\text { Good }\end{array}$ & $\begin{array}{c}\text { Flood preventing, } \\
\text { fair }\end{array}$ & Poor & $\begin{array}{l}\text { Irrigation } \\
\text { Good }\end{array}$ & Poor & Poor \\
\hline Indoor air quality & Fair & Good & Good & Good & Good & Poor \\
\hline Noise pollution & Lessen & Lessen & Lessen & Exist & Exist & Exist \\
\hline $\begin{array}{c}\text { Health and well- } \\
\text { being }\end{array}$ & Normal, good & Healthy & Healthy & Healthy & Healthy & Vulnerable \\
\hline $\begin{array}{c}\text { Biodiversity and } \\
\text { food }\end{array}$ & Flora & Flora & $\begin{array}{l}\text { Flora, } \\
\text { insects }\end{array}$ & Flora, insects & None & None \\
\hline
\end{tabular}

\section{Conclusion}

As it is shown in the table, buildings with vertical farms have a better performance. As their environmental performance is analyzed. Relatively Noah Centrum Apartment has a better performance other than Bedelu building. The other fours' strength is directly related to the presence of the VGS. 
As it is shown the above analysis the thermal strength of Hope University is the effect of the slanted green roof, which directly connected to the concept of water-conserving urban. As well as the buffer on Peace Building.

In general, the two buildings lack biodiversity, defined noise buffer, water efficiency, natural air quality, natural visual performance, closeness to nature, edible plantation and healthy environment. As it is discussed on the previous sections, these defects could easily be solved via VGS.

\section{Recommendation}

These two buildings have their own historical and constructional strength, Bedilu building is one of the ancient architecturally Iconic buildings that found in the CBD of Addis Ababa which is now defined by interior un-hostility, dampness and microbes. Whereas Noah Centrum Apartment, one of the expensive apartments in Addis Ababa, via its location and building quality, but degraded by the listed effects which could be minimized by the application of VGS.

\section{Reference}

1. Alexandri, E. and Jones, P., 2006, September. Ponds, Green Roofs, pergolas and high albedo materials; which cooling technique for urban spaces. In proceedings of the 23rd Conference of Passive and Low Energy Architecture, Geneva, Switzerland.

2. Bal, S. and Pal, S., 2020. Balcony Gardening of Vegetable Crops. Agriculture and Food: E-Newsletter, ISSN, pp.2581-8317.

3. Cohen, B., 2006. Urbanization in developing countries: Current trends, future projections, and key challenges for sustainability. Technology in society, 28(1-2), pp.63-80.

4. Darlington, T.K., Wager-Smith, K., Ceriani, M.F., Staknis, D., Gekakis, N., Steeves, T.D., Weitz, C.J., Takahashi, J.S. and Kay, S.A., 1998. Closing the circadian loop: CLOCKinduced transcription of its own inhibitors per and time Science, 280(5369), pp.1599-1603.

5. Dravigne, A., Waliczek, T.M., Lineberger, R.D. and Zajicek, J.M., 2008. The effect of live plants and window views of green spaces on employee perceptions of job satisfaction. HortScience, 43(1), pp.183-187.

6. Hoyano, A., 1988. Climatological uses of plants for solar control and the effects on the thermal environment of a building. Energy and buildings, 11(1-3), pp.181-199.

7. Pérez-Urrestarazu, L., Fernández-Cañero, R., Franco-Salas, A. and Egea, G., 2016. Vertical greening systems and sustainable cities, Journal of Urban Technology, Pages 65-85.

8. Perini, K., Ottelé, M., Fraaij, A.L.A., Haas, E.M. and Raiteri, R., 2011 . Vertical greening systems and the effect on air flow and temperature on the building envelope. Building and Environment, 46(11), pp.2287-2294.

9. Sheweka, S.M. and Mohamed, N.M., 2012. Green facades as a new sustainable approach towards climate change. Energy Procedia, 18, pp.507-520. 